Editorial

\title{
Special issue of Russian Open Medical Journal dedicated to terahertz waves in medicine
}

\author{
Vyacheslav F. Kirichuk
}

Saratov State Medical University n.a. V.I. Razumovsky, Saratov, Russia

Received 8 November 2013

(C) 2013, Kirichuk V.F.

(C) 2013, Russian Open Medical Journal

Keywords: THz waves, medicine

Cite as Kirichuk VF. Special issue of Russian Open Medical Journal dedicated to terahertz waves in medicine. Russian Open Medical Journal 2013 ; 2: 0401.

Correspondence to Prof. Vyacheslav F. Kirichuk. Address: Department of normal physiology n.a. I.A. Chuevsky, Saratov State Medical University n.a. V.I. Razumovsky, 112, Bolshaya Kazachiya str., Saratov, 410012, Russia. E-mail: normalf@yandex.ru

Electromagnetic waves of extremely high frequency (EHF) are widely used in treatment of various diseases. Currently, employees of the Department of Physiology n.a. I.A. Chuevsky of Saratov State Medical University n.a. V.I. Razumovsky (Saratov, Russia) experimentally justified fundamentally new direction - the use of a new direction - the use of a public health practice terahertz electromagnetic waves of low power at frequencies of cellular metabolites - the natural regulators of numerous cellular functions of the body (nitric oxide, atmospheric oxygen, etc.).

Numerous publications in Russian journals, including "Biomedical Technology and electronics", "Bulletin of Experimental Biology and Medicine", "Russian Journal of Physiology n.a. I.M. Sechenov", "Cytology" and foreign editions over the last ten years have showed that such electromagnetic waves have the ability to normalize various defects of the bloodstream and the microcirculation, the rheological blood properties, prevent the development of intravascular coagulation, exhibit antiinflammatory and analgesic effects, normalize lipid peroxidation of cell membranes and antioxidant protection, have anti-stress effect.

Based on the studies in the Medical Technology Association of EHF (Moscow, Russia) and of the Central Research Institute of instrumentation, Central Research Institute (Saratov, Russia) created an apparatus for terahertz therapy "Orbita" to which the Federal Service on Surveillance in Healthcare and Social development issued a license number 99-03-002043 on 17 June 2010 and registration certificate number FSR 2009/05497 of 14 August 2009 on its production, for sale and use in the Russian Federation.

Terahertz waves at the frequencies of the emission spectrum of molecular and cellular uptake of the universal controller nitrous oxide and atmospheric oxygen is used in the treatment of various diseases of a cardiovascular system, burns, skin tumors, staphylococcal infection used in dentistry, addiction, gynecology, ophthalmology, traumatology, orthopedics and other areas of medicine.

The proposed issue provides to the reader new data about the normalizing effect of terahertz waves at the molecular spectrum of emission and absorption of nitric oxide 150, $176 \ldots 150,664 \mathrm{GHz}$ and $129 \mathrm{GHz}$ atmospheric oxygen to violations in regional and circulatory organs under stress - model violations in the cardiovascular system in various diseases, mechanisms of action are presented for the first time terahertz waves at frequencies of nitric oxide and atmospheric oxygen on disability of the organism.

The clinical section contains articles on the clinical use of terahertz therapy.

\section{Authors:}

Vyacheslav F. Kirichuk - MD, D.Sc. Professor, Honored Scientist of Russia, Head of Department of Normal Physiology n.a. I.A. Chuevsky, Saratov State Medical University n.a. V.I. Razumovsky, Saratov, Russia. 